\title{
JONATHAN I. CHARNEY (1943-2002)
}

Jonathan I. Charney, co-editor in chief of this Joumal since 1998, died in Nashville, Tennessee, on September 7, 2002, after a long and courageous battle with cancer, leaving his wife, Sharon, and three children. He was fifty-eight years old.

I.

Professor Charney was born in New York and received his BA in 1965 from New York University. He earned his JD in 1968 from the University of Wisconsin School of Law, where he was a member of the law review and was elected to the Order of the Coif. Upon graduation he went directly to the United States Department of Justice, where he served as an attorney in the appellate section for one year before moving to the marine resources section. He served there as an attorney for two years and then became the chief of that section.

In 1972 Charney accepted an appointment to the School of Law at Vanderbilt University where, six years later, he became a full professor. In 1999 he was designated the Alexander Heard Distinguished Service Professor and in 2001 assumed the chair of the Speir Professorship.

Charney's devotion to teaching did not prevent him from the most active participation in the major institutions concerned with research and policy clarification regarding international law. He was a member of the Council on Foreign Relations and the American Law Institute and on the Board of Editors of Ocean Development and International Law for almost twenty years. He also served as a member of the Board of Advisors of the International Boundary Research Unit at the University of Durham and was long the chair of the Senior Advisors Committee for the Marine Policy Center at Woods Hole. He chaired research committees of the American Bar Association and the American Branch of the International Law Association, as well as many research committees of the American Society of International Law.

In addition to his service in the Department of Justice, Charney was a member of the United States delegation to the Third United Nations Conference on the Law of the Sea from 1974 to 1982, and during that same period served on the United States Advisory Committee on the Law of Sea. He was consulted, as well, by many other governments on matters of international law.

II.

Jonathan Charney was one of the leading international legal scholars of his generation. He was an authority on the law of the sea and his magisterial four-volume work on international maritime boundaries quickly became the vade mecum for anyone involved in virtually any aspect of the law of the sea. But law of the sea formed only a small part of his expansive oeuvre. He wrote authoritatively on the use of force and humanitarian intervention, selfdetermination, customary international law, and, in particular, soft law, international environmental law, international tribunals and jurisdiction, technology, and constitutional law. All of his work was marked by a concern for theoretical questions, extraordinary attention to detail, and efforts to discover how law might contribute to resolving the problem he was addressing. 
While every aspect of international law that Charney wrote on was influenced by him, he leaves an indelible mark in two particular areas. Thanks to his indispensable study of maritime boundary delimitation (initially with Lewis Alexander and later with Robert Smith), the international community will long link his name with the subject. International tribunals already speak as naturally of "Charney on International Maritime Boundaries" as they do of "Oppenheim on International Law" and "Wigmore on Evidence." In this study, he designed a comprehensive review of maritime boundaries and incorporated the efforts of a large number of experts, who were recruited worldwide but subjected to the discipline of his scholarly standards. More than a report on the status of boundaries, it is, in its entirety, an impressive study of state practice. Indeed, it is one of the few such studies to fit the meaning of Article 38(1) (b) of the Statute of the International Court of Justice.

While the area of state practice in maritime boundary delimitation continued to occupy him, as successive volumes of his magnum opus appeared, he also found time to address other large problems confronting international law. He was one of the earliest scholars to appreciate the constitutional implications of the multiplication of international tribunals, their likely interrelations and possible jurisdictional and jurisprudential conflicts, and the policy implications of this development. This area had already become controversial, in some quarters taking on overtones of hysteria. In his remarkable Hague lectures of 1998, Charney characteristically reviewed every extant and projected tribunal, examined the extent to which overlapping jurisdictions might create a jurisprudential cacophony, and provided his audience with a sober appraisal grounded in empirical detail and realistic scenarios of the future.

\section{III.}

Professor Charney's service to the American Journal of International Law, both as a member of the Board of Editors since 1986 and as co-editor in chief, constituted a major personal contribution to international scholarship. Over the years, he published many articles and editorials in the Joumal, chaired various committees of the Board of Editors, and was one of its most active and respected members.

Charney was also well versed in information technology and presided over the challenging task of converting the Journal from its old-fashioned production to the most up-to-date desktop procedures. Those who worked on the Journal with him, either as co-editor, fellow board member, production assistant, or author of a piece being prepared for publication, encountered a precise and analytic mind, an enormous range of knowledge, and an uncompromising demand for accuracy. He was a man of principle and when principles were at stake, he could be hard, but he was never harsh. The characteristic energy and drive of the native New Yorker blended over the years with the characteristic courtesy and graciousness of a Southern gentleman, producing in one person the best of all possible worlds.

\section{IV.}

All those who had the pleasure of working with Jonathan Charney will always remember how intense he could be in discussions on any subject of international law. He would lean forward in concentration, focusing on the issue in question, before suddenly leaning back, tipping his head to one side, and narrowing his eyes until they crinkled with good humor. Then his face would glow, with a slow, wonderful smile, over the sheer delight, even glee, of intellectual exchange.

The Board of Editors of the American Journal of International Law grieves not only for the loss of our colleague and friend, but also for the loss to the study and advance of international law of a splendid scholar and a great and good man. 